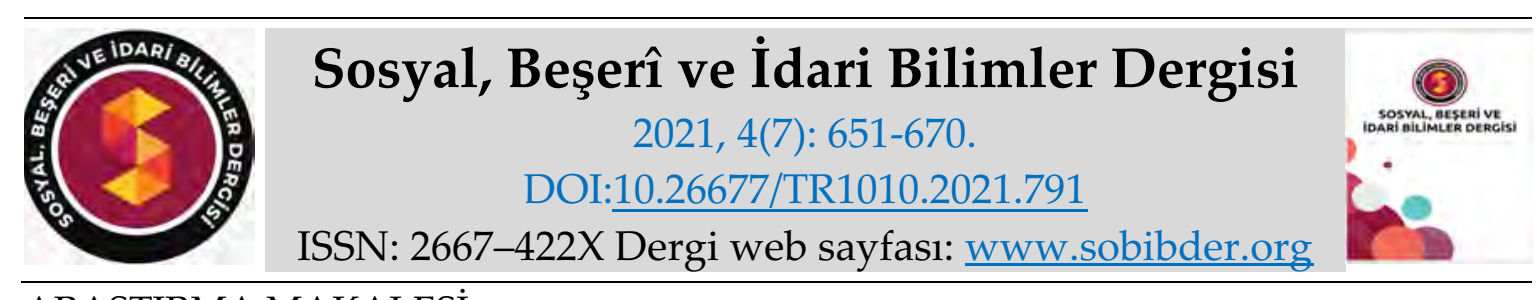

ARASTTIRMA MAKALESI

\title{
Türkiye' de 1995-2020 Yılları Arasında Çocuk İstismarını Önleme Programlarına İlişkin Gerçekleştirilen Çalışmaların İncelenmesi ve Değerlendirilmesi*
}

\author{
Uzm. Psikolog Gözde Ece DEREBAGÇE, Bağımsız Araştırmacı, e-posta: \\ g.e.derebagce@gmail.com \\ ORCID: https://orcid.org/0000-0002-6054-534X
}

Dr. Psikolog Halis ÖZERK, Halis Özerk Psikoterapi ve Eğitim Enstitüsü, İstanbul, e-posta: halisozerk@halisozerk.com

ORCID: https://orcid.org/0000-0001-5530-6638

Öz

Dünya Sağllk Örgütü (WHO; World Health Organization)'nün hemen her yıl dikkat çektiği rakamlara bakıldığında tüm dünyada çocuk istismarı ve ihmalinin gün geçtikçe artmakta olduğu görülmektedir. Benzer biçimde gerek TÜIK gerek Sağlık Bakanlığı gerekse Emniyet Genel Müdürlüğü verileri çocuk istismarı ve ihmalinin Türkiye'de de hemen her yıl daha fazla görüldügüne işaret etmektedir. Bu çalışmanın amacı, Türkiye'de 1995-2020 yılları arasında istismar önleme programına dair yapılmış olan araştırmaları değerlendirmektir. Araştırmanın modeli betimsel tarama modelidir. Araştırmalardaki çalışma gruplarının en çok çocuklardan oluştuğu, çalışmaların en çok bilgi düzeyi arttırma ve beceri edindirme amaçlı yapıldığı, tüm istismar türlerini kapsayan araştırmaların diğerlerine göre daha yoğun olduğu sonuçlarına varılmıştır. Araştırmaların yıllara göre dağılımına bakıldığında 2011-2015 yılları arasında araştırma sayısında artış görüldüğü ve en fazla artışın 2016-2020 yılları arasında olduğu sonucuna varılmıştır. İstismarların ise \%45.45' inin tüm istismar türleri, \%42.42' sinin cinsel istismar ve \%12.12' sinin ise duygusal istismar ve ihmal şeklinde bir dağılım gösterdiği sonucuna varılmıştır.

* Çalışma, Gözde Ece DEREBAGÇE'nin Klinik Psikoloji Yüksek Lisans (Tezsiz) Programı bitirme projesinden (2019-2020) üretilmiştir.

Anahtar Kelimeler: Klinik Psikoloji, Çocuk İstismarı, İhmal.

Makale Gönderme Tarihi: 14.04.2021

Makale Kabul Tarihi: 01.07.2021

Önerilen Atıf:

Derebagçe, G. E. ve Özerk, H. (2021). Türkiye'de 1995-2020 Yılları Arasında Çocuk İstismarını Önleme Programlarına İlişkin Gerçekleştirilen Çalışmaların İncelenmesi ve Değerlendirilmesi, Sosyal, Beşeri ve İdari Bilimler Dergisi, 4(7): 651-670.

(c) 2021 Sosyal, Beşerî ve İdari Bilimler Dergisi. 


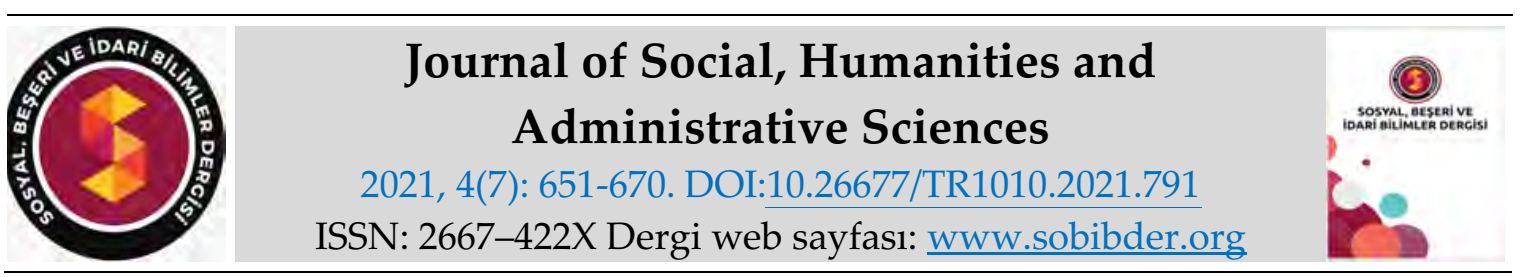

RESEARCH PAPER

\title{
The Analysis and Discussion Regarding the Researches Concerning Child Abuse Prevention Programs From 1995-2020 in Turkey.
}

\section{Exp. Psychologist Gözde Ece DEREBAGÇE, Independent Researcher, e-mail: g.e.derebagce@gmail.com \\ ORCID: https://orcid.org/0000-0002-6054-534X}

Dr. Psychologist Halis ÖZERK, Halis Özerk Psychotherapy and Training Institute, İstanbul, email:halisozerk@halisozerk.com ORCID: https://orcid.org/0000-0001-5530-6638

\begin{abstract}
Considering the figures that the World Health Organization (WHO) draws attention almost every year it is seen that child abuse and neglectis increasing day by day in the whole world. Similarly, TÜIK, both of Ministry of Health and Security General Directorate's datas indicates that in Turkey; child abuse and neglect have seen more frequent every year. The aim of this study is to evaluate the research done in the years between 1995-2020 that on the abuse preventing program. The model of the research is descriptive scanning model. It was concluded that the study groups in the studies consisted mostly of children, the studies were conducted mostly to increase the level of knowledge and acquire skills, and the studies covering all types of abuse were more intense than the others. Considering the distribution of the studies by years it was concluded that there was an increase in the number of studies between 2011-2015 and the highest increase was between 2016-2020. On the other hand, it was concluded that $45.45 \%$ of the abuses showed a distribution as all types of abuse, $42.42 \%$ as sexual abuse and $12.12 \%$ as emotional abuse and neglect.
\end{abstract}

Keywords: Clinical Psychology, Child Abuse, Neglect.

Received: 14.04 .2021

Accepted: 01.07.2021

\section{Suggested Citation:}

Derebagçe, G. E. and Özerk, H. (2021). The Analysis and Discussion Regarding the Researches Concerning Child Abuse Prevention Programs From 1995-2020 in Turkey., Journal of Social, Humanities and Administrative Sciences, 4(7): 651-670.

(c) 2021 Sosyal, Beşerî ve İdari Bilimler Dergisi. 


\section{Gíriş}

Çocuk istismarı ve ihmali, tüm dünyada olduğu gibi Türkiye'de de gözlemlenen büyük bir toplumsal sorundur. Birleşmiş Milletler Çocuklara Yardım Fonu; kısaca UNICEF (United Nations International Children's Emergency Fund), dünyada 2-4 yaş aralığındaki 300 milyon çocuğun, bakım veren kişiler tarafından psikolojik saldırıya ve/veya fiziksel cezaya maruz bırakıldığını belirtmiştir. Yine aynı yıl 1-19 yaş aralığındaki yaklaşık 15 milyon kız çocuğunun yaşamlarının bir kısmında cinsel ilişkiye ya da herhangi bir cinsel eyleme zorlandığını belirtmiştir (UNICEF, 2017). Aynı kuruluş 2020 yılında yayımladığı basın bülteninde ise halk sağlığı ile ilişkili daha önce yaşanan olağanüstü durumlarda çocuk istismarı ve ihmali olaylarında artış gözlemlendiği için, bu yıl yaşanan olağanüstü durumun da (pandemi) riski arttıracağını öngörmekte ve önlemler alınması gerektiğine dair vurgu yapmaktadır (UNICEF, 2020). Öncesinde yani 2010 yılında yayımladığı raporda da 7-14 yaş aralığındaki kız çocuklarının en çok anne, baba, öğretmen, arkadaş ve büyük kardeşler tarafından, erkek çocukların ise sırasıyla, arkadaş, öğretmen, baba, büyük kardeş ve tanımadıkları birinin fiziksel istismarına uğradıklarını, 15-18 yaş aralığındaki erkeklerin ise, kızlardan çok daha fazla istismara maruz kaldıklarını bildirmiştir.

Türkiye özelinde verilere bakılacak olursa; 2019 yılında emniyet birimlerine suç mağduru olarak gelen 206 bin 498 çocuktan \%15,2'sinin cinsel suçlar, \%57,6'sının yaralama nedeniyle geldiği görülmektedir (Türkiye İstatistik Kurumu [TÜİK], 2020).

Yine Türkiye' de Ceza Mahkemeleri'nde çocukların cinsel istismarı konusunda açılan davalardaki suç sayısı 2012 yılında 17 bin 589 iken, 2019 yılında 22 bin 689'a yükselmiştir (Adli Sicil ve İstatistik Genel Müdürlüğü, 2019).

Tüm dünyada bir problem olarak görülen çocuk istismarı için birçok önleme programı oluşturulmuştur. Çocukları istismardan koruma amacıyla oluşturulan önleme programları için birincil, ikincil ve üçüncül önleme olarak üç basamaktan bahsedilmektedir. Birincil Önleme; risk grubunda bulunsun ya da bulunmasın toplumsal farkındalığı arttırmaya yönelik çalışmaların yapıldığı; çocuğa ya da aileye eğitim vermek, durumlarının iyileştirilmesi, yaşam kalitelerinin arttırılması gibi yöntemlerle istismar ortamını oluşturan riskleri ortadan kaldırmayı amaçlayan önleme programlarıdır. İkincil Önleme; risk gruplarının belirlenmesini, risk grubundaki kişilerin sunulan hizmetlere ulaşabilmesini amaçlamaktadır. Erken tanı, tedavi, bakım ve izlem çalışmalarını kapsayan önleme programlarıdır. Üçüncül Önleme istismarın gerçekleştiği durumda hem zararı azaltmaya yönelik hem de tekrarlanmasını ve daha kötü (ölüm gibi) sonuçların ortaya çımasını engellemeye yönelik oluşturulan önleme programlarıdır (Acehan, Bilen, Ay, Gülen, Avcı ve İçme 2013; Demirtürk Selçuk ve Karadeniz, 2020).

Çalışma, yukarıdaki açıklamalara dayalı olarak, önleme programları basamakları, hedef kitle ve çalışmaların yürütüldügü kurum ve kuruluşlar çerçevesinde ele alınmış ve bu çerçevede yürütülen araştırmalar ve bulgular incelenmiştir. Bulgular tüm araştırmalar çerçevesinde de değerlendirilmiş, yorumlanmış ve önerilerde bulunulmuştur.

Yapılan araştırmalar istismar önleme programlarının gerekliliğinin ve öneminin fark edilebilmesini sağlamaktadır. Bu bilgiler ışığında Türkiye'de uygulanan istismar önleme programlarının niteliklerini ve sonuçlarını değerlendirmenin çocukları istismara karşı korumak için yararlı olabilecek ve ihtiyaç duyulabilecek programların oluşturulması ya da var olan programların geliştirilmesi konusunda yararlı olacağı düşünülmektedir.

Bu bağlamda çalışmanın amacı, Türkiye'de 1995-2020 yılları arasında istismar önleme programına dair yapılmış olan araştırmaları; uygulamayı onaylayan bakanlık, uygulamanın türü, uygulandığı grup, istismar türü, çalışmanın yapıldığı pilot şehir, yapıldığı yıl bazında incelemek ve değerlendirmektir. Aynı zamanda gelecekte yapılacak çalışmalara rehberlik 
edebilmesi ve yapılan uygulamalar değerlendirildiğinde ortaya çıkacak olan eksikliklerin yapılacak yeni uygulamalara yön verebilmesi hedeflenmiştir.

\section{KURAMSAL ÇERÇEVE ve İLGİLI ÇALIŞMALAR}

WHO (World Health Organization; Dünya Sağlık Örgütü [DSÖ], 1999), istismar ve ihmal kavramını birlikte ele alarak, Çocuk İstismarı Önleme Toplantısı Raporu'nda çocuk istismar ve ihmalini "Çocuğun hayatta kalmasına, gelişimine, sağlı̆̆ına ya da özsaygısına zarar verme potansiyeli ile sonuçlanan güven, sorumluluk ve güç ilişkisi bağlamında oluşan her türlü fiziksel, duygusal, cinsel suiistimal, ihmal ya da ihmalkâr muamele, ticari ve diğer suiistimallerden oluşan durumlar" olarak tanımlamaktadır.

Türk Dil Kurumu (TDK: Türk Dil Kurumu; 2020) istismarı, "Birinin iyi niyetini kötüye kullanma" şeklinde tanımlamaktadır.

T.C. Sağlık Bakanlığı (2021)'nin ise ihmal kavramını istismarın dört farklı boyutundan (fiziksel, cinsel, duygusal ve ihmal) biri olarak ele aldığı ve ihmali "Çocuğa bakmakla yükümlü kimselerin; çocuğun beslenme, giyinme, barınma, eğitim, sağllk, diş sağhlğı ve sevgi gibi temel gereksinimlerini karşılamada ihmal göstermesi, çocuğun beden ve ruh sağllğının veya bedensel, duygusal, sosyal ya da ahlaki gelişiminin engellenmesi" olarak tanımlamaktadır. Diğer üç boyut ise şu şekilde tanımlanmaktadır.

Fiziksel İstismar: Çocuğa karşı, sağlığına, yaşamına, gelişimine veya onuruna zarar veren ya da zarar verebilme olasılığı yüksek, kasıtlı fiziksel güç kullanılmasıdır.

Cinsel İstismar: Çocuğun tam olarak anlayamadığı, onay vermesinin mümkün olamayacağı, gelişimsel olarak hazır olmadığı ya da toplumun yasalarına, sosyal normlarına aykırı olacak şekilde bir cinsel etkinliğe dahil edilmesidir.

Duygusal İstismar: Ebeveyn ya da çocuğa bakan kişinin davranışları ya da sözleriyle çocuğun ruh sağlığını bozacak etkide bulunması ve çocuğun bu nedenle büyüme gelişme ve ruh sağlı̆̆ı açısından genetik kapasitesine ulaşmasının engellenmesidir.

Yazılı kaynakların başından itibaren çocuk istismarının varlığına dair ipuçlarına rastlanmaktadır. Çocuklar ilkçağlarda kurban edilme, köle olarak satılma; orta çağda ise şiddet, erken evlilik gibi çeşitli istismar türlerine maruz kalmaktaydı (Ata, 2019).

1860 yılında Tardieu Fransa'da çocuklara yapılan fiziksel ve cinsel saldırılardan bahsetmiştir. 1946 yılında radyolog olan Caffey, acile getirilen çocukların durumlarından şüphelenerek çağdaş tıp literatüründe konuyla ilgili ilk raporu yayınlamıştır (American Academy of Child Adolesant Psychiatry [AACAP], 1997). Tanımlanması ise son yüzyılda, 1962 yılında Kempe tarafından "örselenmiş çocuk" teriminin ortaya atılması ile gerçekleşmiştir. İlerleyen süreçte tanım "çocuk istismarı" şeklinde değiştirilmiştir (Kara, Biçer ve Gökalp, 2004).

Çocuk İstismarı ve ihmalini açıklamaya yönelik birçok kuram, kuramlara dayalı model vardır.

\section{PSİKİYATRIK KURAM}

Psikiyatrik kuram, istismarda sorumlunun genellikle anne ve baba olduğunu belirtir (Bayraktar, 2015:45). Bu yüzden istismar nedenlerini açıklarken ebeveynin özelliklerini temel alır (Yıldırım Doğru, 2020:91). Bu kuramda çocuk istismarı ve ihmalinin nedeni olarak anne-babanın psikopatolojisi gösterilir (Yılmaz Irmak, 2008). Diğer ailelerden farklı olarak istismarcı ailenin psikiyatrik belirtilerinin olması gerektiğini savunmaktadır (Yıldırım Doğru, 2020:91). 
Çocuk istismarı konusunu bilimsel bir yayın ile ilk kez duyuran Kempe ve arkadaşları da çocuk istismarı faillerinin klinik bir tanı almaları gerektiği ve bu durumun bir hastalık olduğu görüşünü savunmuşlardır (Buchanan, 1996, Giovannoni, 1991; akt. Yılmaz Irmak, 2008). Ancak yapılan klinik gözlemler ve incelemeler istismar eden ebeveynlerin \%10'unun psikiyatrik hasta olduğunu göstermiştir (Kars, 1994; akt. Yıldırım Doğru, 2020:91). Yapılan bir çalışmada çocuklarını öldüren babaların 1/3'ünün depresif özellikler gösterdiği bulgulanmıştır (Polat, 2017:48).

Yine psikiyatri kuramcılarının yaptıkları çalışmalarda çocukları istismar eden annelerin; öz saygılarının düşük olduğu, çocuğu reddetme duygusuna sahip olduğu ve doyumsuzluk içinde oldukları tespit edilmiştir. Ayrıca psikopatik eğilimlerini normal bir görünüş ile gizleyebildikleri iddia edilmektedir (Tercan,1995; akt. Siyez,2003). Ebeveynlerin kişilik özelliklerine ilişkin çalışmalarda çocuk istismarı ile ilgili olduğu düşünülen bazı kişilik özellikleri dikkat çekmiştir. Bunlar; narsistik eğilimler, impuls zayıflı̆̆ı, kompulsivite, kaygı, depresyon, empati kuramama gibi özelliklerdir (Polat, 2017:47). Bu görüş istismarc1 profilinin belirlenmesinin mümkün olduğunu düşündürmektedir. Fakat tüm istismar türleri düşünüldügünde istismarcı profiline ulaşmanın pek de mümkün olmadığı görülmüştür (Yılmaz Irmak, 2008).

\section{SOSYOLOJIKK MODEL}

Sosyolojik Kuram; toplumsal kuralların, değerlerin, kültür ve aile yapısının istismara yol açan faktörler olduğunu belirtir (Bayraktar, 2015:45). Kurama göre, toplum, çevre, kitle iletişim araçlarına aksedilen şiddet ve çevresel baskı, istismarın temelinde yatan nedenlerdir (Kars,1994; akt. Yıldırım Doğru, 2020:94). Hem kitle iletişim araçları hem de kişiler arası ilişkilerde onaylanan şiddet düzeyinin çocuklara uygulanan fiziksel cezanın sıklığı ve şiddetine yansıdığı görülmesi bu kurama dayalı olarak açıklanır (Polat, 2017:50). Ailenin toplumdan soyutlanması, sık sık ev ve iş değiştirme gibi durumlar modern toplumlarda istismara yol açan nedenler arasındadır. Endüstrileşme ve kentleşme; aile yapılarının geniş aile yapısından çekirdek aile yapısına dönüşmesiyle çocuk yetiştirme ve diğer konularda sosyal desteğin azalmasına sebep olarak çocuk istismarı olasılı̆̆ının artmasına katkı sağlamaktadır (Yıldırım Doğru, 2020:94). Ayrıca istismara yol açtığı bilinen bir diğer sorun da ailede stres ve bunalım yaratan durumlardır. Kuram, stres ve engellemenin de çocuk istismarına yol açtığını varsaymaktadır (Polat, 2017:50; Yıldırım Doğru, 2020:94). Kuram, bu sorunların sadece alt sosyo-ekonomik düzeye sahip ailelere özgü işsizlik, düşük gelir düzeyi, ailede çocuk fazlalığı gibi durumlar olmadığı; aile içinde geçimsizlik gibi her tür sosyo-ekonomik düzeye sahip ailede karşılaşılabilecek durumları da içerdiğini ileri sürer. Türk toplumu da geleneksel uygulamalardan etkilenen toplumlar arasındadır (Polat, 2017:50-54).

\section{SOSYAL ÖĞRENME MODELI}

Davranışların kişisel ve çevresel değişkenlerin sürekli bir etkileşiminin sonucu olduğunu savunan bu kuram, temelde insanların model alarak öğrendiği varsayımına sahiptir (Yıldırım Doğru, 2020:92). Bu bağlamda da istismarı, öğrenilmiş bir etkileşim durumu olarak tanımlar (Bayraktar, 2015:45). Kuram çocuk istismarının çevresel değişkenler ve karşılıklı kişisel etkileşimin ortaya çıkardığı davranışlar şeklinde oluştuğu temel varsayımına dayanır.

Çocukluklarında istismara uğramış ebeveynlerin, çocuklarına yönelik davranışlarında kendi ebeveynlerinin davranışlarını modelledikleri gözlemlenmiştir (Polat, 2017:48). Kuram, ebeveynlerin kendi ebeveynlerini örnek aldıklarını ve çocuklarına karşı gerçekçi olmayan beklentilere sahip olduklarını iddia etmektedir. Buna göre çocukluğunda şiddet görmüş ebeveynler, onlara şiddet uygulayan yetişkinleri örnek alarak çocuklarına şiddet 
uygulamaktadır. Bu durum "Kuşaklar Hipotezi" olarak isimlendirilmektedir (Sweet ve Resick, 1979; akt. Siyez, 2003). Kaufman ve Zigler $(1987,1989)$ bu kuşaklar arası geçişi inceledikleri çalışmada istismar mağduru kişilerin istismarcı olma olasılıklarının yüksek olduğunu; fakat yaptıkları çalışmadaki istismar mağdurlarının \%30 oranında istismarcı olduklarını, her istismara uğramış kişinin istismarcı olmadığını ifade etmişlerdir (akt. Yılmaz Irmak, 2008).

\section{SOSYAL PSIKKOLOJİK MODEL}

Sosyal Psikolojik kuram, toplum ve bireyin psikopatolojilerini temel alarak insan davranışlarını değerlendirir (Yıldırım Doğru, 2020:93). Şiddet ve saldırganlıkla ilgili rol modeller, toplumsal statü, değer ve normlar toplumsal durumlar içerisindedir (Siyez, 2003). Modelin öncülerinden Gelles çocuk istismarının nedenlerini psiko-patolojik durumlar ve toplumsal durumlar olarak kategorilere ayırır. Finkelhor ise çocukların cinsel istismara uğramasına neden olan faktörleri kişisel, psikolojik ve sosyal açıdan değerlendirerek cinsel istismarı dört koşul altında açıklar. Birinci koşul, saldırganın cinsel istismar motivasyonudur. Çocuklara karşı cinsel istismar davranışı görülen kişiler; duygusal açıdan olgunlaşmamış, yetişkin bireylerle cinsel ilişkiyi tehdit edici gören, reddedilme ya da yetersizlik korkusu yaşayan, cinsel doyum kaynaklarına ulaşamayan ya da cinsel doyum kaynakları yeterince tatmin edici olmayan kişilerdir. Bu kişiler çocukları kolay ulaşılabilen objeler olarak görürler. İkinci koşul, içsel engelleyici etkenlerin yıkılmasıdır. Bireyin kendine güvenini tehdit edecek stres durumları, evlilik sorunları, evlilik ilişkisinin işlevselliğini yitirmesi, kültürel normlar, alkol veya madde kullanımı, psikopatolojiler, yaşlılık, toplumsal hoşgörü ve cinsel saldırganlara yönelik hukuki yaptırımların yetersizliği gibi faktörler istismarcının çocukla cinsel etkileşimde bulunmasında etkilidir. Üçüncü koşul, dışsal engelleyici etkenlerin yıkılmasıdır. Çocuğun cinsel istismara uğrama riskini arttıran etkenler; ebeveyn-çocuk arasındaki bağ gelişiminin yetersiz olması, anne yoksunluğu ya da annenin hasta olma durumu, ebeveynlerin bakım verme konusunda yetersizliği, katı aile yapısı, aile içi şiddet, ailenin veya annenin sosyal destek eksikliği gibi etkenlerdir. Dördüncü koşul, çocuğun direncini kıran etkenlerdir. Çocuk cinsel istismarına uğrama riski daha fazla olan grup; fiziksel, zihinsel ya da gelişimsel engeli bulunan, terk edilmiş, duygusal olarak yoksun bırakılmış ve sosyal açıdan yalnız olan, cinsel istismar hakkında bilgisi olmayan çocuklardır (Finkelhor, 1984; akt. Z-Page, 2004).

\section{SOSYAL DURUMSAL MODEL}

Sosyal Durumsal model çocuk istismarı ve ihmalinin ebeveynlerin çocuklarına karşı kullandıkları hatalı ve tutarsız disiplin tutumları ile arttığı görüşünü savunur. Yapılan araştırmalar, çocuklarını istismar eden ebeveynlerin etkisiz ve tutarsız disiplin yöntemlerine başvurduklarını göstermiştir. Bu tarz tutarsız ve çelişkili yöntemler çocuklarda sapkın davranışlara yol açabilmektedir (Yıldırım Doğru, 2020:92). Bu tutumlarla sürekli karşılaşan çocuk korku ve kaygı yaşayabilir. Çoğunlukla çelişkili davranışlara maruz kalan çocuklar bağımlı bir kişilik yapısına sahip olmaktadır (Yılmazer, 2007; akt. Dursun, 2010).

\section{Psikanaliz Kuramı}

Psikanaliz kuramı, istismar uygulayan kişilerin insanlara karşı düşmanca ve yıkıcı davranışlarından çocukluk döneminde yaşadıkları yaşantıların sorumlu olduğunu savunmaktadır (Yıldırım Doğru, 2020:93). Cinsel istismarın nedenlerine dair açıklamaları, ensest ile ilgili açıklamaktadır. Kökeni Freud'un Odipus Kompleksi'ne dair klinik gözlemlere 
dayanmaktadır. Freud ilk yayınlarında yetişkin kadın hastaların büyük kısmının verdiği cinsel istismar öykülerine dayanarak, erişkin döneminde çıkan ruhsal rahatsızlıklarla çocukluk döneminde yaşanan cinsel travmanın birbiriyle nedensel bir ilişkiye sahip olduklarını savunmuştur. İlerleyen yıllarda ise bu düşüncenin yerini cinsel istismar öykülerinin bir fantezi olabileceği düşüncesi almıştır. 60'1 yıllara kadar hâkim olan bu düşünce çocukluk dönemine ait baştan çıkarılma fantezisinin ensest ilişkinin asıl nedeni olduğunu iddia etmiştir. Psikanalitik kuramda Oidipus Kompleksi kadınlarda sosyalleşmenin bir aşaması olarak görülmektedir. Bu kompleks ile kadınların cinsiyetlerine uygun rolleri kazandığı iddia edilmektedir (Topçu, 1997:184).

\section{Sosyal Etkileşimsel Model}

Sosyal Etkileşimsel model; istismarı tek bir kuramın açıklayamayacağını, açıklama için tüm kuramların kombinasyonuna ihtiyaç olduğunu belirtir (Bayraktar, 2015:45). İstismar davranışını her yönü ile ele alan bir modeldir. İstismarın sadece çocukluk yaşantılarının bir sonucu değil, aynı zamanda ebeveyn ve çocuk etkileşiminin de bir sonucu olduğu belirtilmektedir. Kuram, istismar nedenlerini hem çocuk hem anne-baba için ayrı ayrı değerlendirmenin doğru olacağını savunmaktadır (Yıldırım Doğru, 2020:94-95).

Cicchetti ve Rizley (1981) çocuk istismarının hem kuşaklararası geçişini hem de risk faktörlerini açılayabilmek için etkileşimsel modeli geliştirmişlerdir. Çocuk istismarı ve ihmali alanı için Samefoff ve Chandler'e ait olan gelişimin etkileşimsel modelinden uyarlama yaparak bu modeli oluşturduklarını ifade etmişlerdir. Bu modelde risk faktörleri, istismar arttırıcı ve ödünleyici olabilecek faktörler şeklinde iki başlık altında toplanmaktadır. Ayrıca bu faktörlerin her biri için de geçici ve kalıcı faktörler şeklinde bir ayrım daha yapılmaktadır (akt. Yılmaz Irmak, 2008).

Arttırıcı faktörlerden kalıcı olan faktörler "İncinebilirlik Faktörleri" olarak isimlendirilmiştir. Bu faktörler çocuğun güç mizacı ya da engel durumunun bulunması gibi biyolojik olabileceği gibi ebeveyninin çocukluğunda istismara maruz kalmış olması gibi tarihsel de olabilir. Yine düşük engellenme toleransı, psikopatoloji gibi psikolojik olabileceği gibi kültürel olarak kabullenilmiş çocuk yetiştirme ve disiplin yöntemleri gibi sosyo-kültürel ya da maddi yetersizlik, düşük iş fırsatları, zayıf fiziksel çevre, yetersiz ebeveynlik becerileri gibi durumsal özellikler de olabilmektedir.

Arttırıcı faktörlerden geçici olan faktörler de "Zorlayıcı Faktörler" olarak isimlendirilmiştir. Bu faktörler ebeveynin istismarcı olma eğilimini arttırabilecek, kişiyi ve aileyi rahatsız edecek geçici stres veya zorlayıcılardır. Kayıp yaşantıları, fiziksel yaralanma veya hastalanma, evlilik veya aile problemleri ve disiplin problemleri gibi özellikler olabilecekleri belirtilmektedir.

Ödünleyici faktörlerden kalıcı olan faktörler "Koruyucu Faktörler" olarak isimlendirilmiştir. İstismarın gerçekleşme riskini veya onun kuşaklararası geçişini azaltabilecek kalıcı şartlar veya özelliklerdir. Bu faktörler; iyi mizaç, yüksek zekâ, uyum becerisinin yüksek olması, esneklik, fiziksel olarak çekici olmak, sosyal ve insan ilişkilerindeki beceriler, yetenekler, uygun baş etme becerileri, problem çözme becerileri ve iyi ebeveynlere sahip olma geçmişi gibi özelliklerdir.

Ödünleyici faktörlerden geçici olan faktörler ise "Tampon Faktörler" olarak isimlendirilir. Bu faktörler hem aileyi hem de bireyi stresten ve zorlayıcılardan koruyabilecek veya bunları engelleyebilecek geçici özellik veya faktörlerdir. Yüksek maddi kazanç, iyi bir iş ve sosyal destek sistemi gibi özellikler olası tampon faktörlerdir. 
Etkileşimsel model, istismarı arttıran faktörlerin koruyucu faktörlerden daha fazla olduğu durumda istismarın gerçekleştiğini belirtmektedir. Bu yaklaşım ekolojik yaklaşım olarak da isimlendirilmektedir.

\section{Çocuk İstismarına İlişkin Çalışmalar}

Yurtiçi araştırmalara bakıldığında; 1995-2016 yılları arasında gerçekleştirilen çalışmaların çoğunun tanımlayıcı türde olduğu, çoğunda genel çocuk ihmali ve istismarının birlikte çalışıldığı, örneklem grubunun çoğunlukla çocuk ve ergenlerden oluştuğu saptanmıştır (Bakır ve Kapucu, 2017). Yapılan bir başka çalışmada, çocuk istismarını konu alan tezlerin son yıllarda artış göstermekle birlikte, sayıca yetersiz olduğu sonucuna varılmıştır. Ayrıca araştırmaların çoğunun tarama yöntemi ile yapıldığı ve katılımcıların çoğunluğunun çocuk ve ergen olduğu bulgusuna ulaşılmıştır (Beyazıt, 2015).

Yüksek Öğretim Kurum (YÖK) Ulusal veri tabanında 1989-2016 yılları arasında yayımlanan lisansüstü tezlerin adli bilimler açısından değerlendirildiği bir araştırmada 160 tez incelenmiştir. $\mathrm{Bu}$ tezlerin 109'unun yüksek lisans, 29'unun doktora, 22'sinin tıpta uzmanlık tezi olduğu saptanmıştır. 1989-1999 yıllarında 13 tezin, 2000-2009 yıllarında 38 tezin, 2010-2016 yılları arasında ise 108 tezin yayımlandığ tespit edilmiştir. 2010 yılından itibaren konu ile ilgili tez sayısında artış gerçekleştiği görülmektedir (Erkan, 2018).

Çeçen- Eroğul ve Kaf-Hasırcı (2013) tarafından yapılan bir araştırmada İlköğretim 4. Sınıf öğrencilerine cinsel istismarı önleme psiko-eğitim programı uygulanmış ve psiko-eğitimin öğrencilerin cinsel istismar hakkındaki bilgilerini arttırma konusunda etkili olduğu ve bu etkinin 8 hafta boyunca devam ettiği bilgisine ulaşılmıştır.

Akgiray (2007) tarafından yapılan araştırmada 8-10 yaş arası bir grup çocuk ve çocukların ebeveynleri ile çalışılmıştır. İstismarı önleme amacıyla çocuklara sözel, ebeveynlere ise yazılı bilgilendirme yapılmış ve yapılan bilgilendirmelerin sonucunda istismar hakkındaki bilgi düzeylerini arttırdığı sonucuna varılmıştır.

Adalı (2007) tarafından yapılan araştırmada da 10-12 yaş arası bir grup çocuğa eğitim programı uygulanmış, ebeveynlere de bilgilendirici bir broşür dağıtılmıştır. Yapılan uygulamaların istismar hakkındaki bilgi düzeylerini arttırdığı sonucuna varılmıştır.

Sarı ve Güngör Aytar (2015) tarafından çocuklara yönelik istismar potansiyellerini belirlemek amacıyla yapılan çalışmada Emniyet örgütünde görevli anne-babalar ile çalışmada gerçekleştirilen "Aile Eğitim Programı" sonrası eğitim programına katılan bireylerin istismar potansiyel puanlarında düşüş olduğu sonucuna varılmıştır.

2013-2016 tarihleri arasında bir poliklinikte izlenmekte olan cinsel istismara uğramış çocuk ve ergen olguların çoğunun istismar sonrası en az bir psikiyatrik tanı aldığı saptanmıştır. Alınan tanılar; travma ve tetikleyici etkenle ilişkili bozukluklar, depresif bozukluklar, anksiyete bozuklukları, madde ile ilişkili bozukluklar, takıntı zorlantı bozukluğu ve ilişkili bozukluklar, dikkat eksikliği ve aşırı hareketlilik bozuklukları, yıkıcı bozukluklar dürtü denetimi ve davranım bozukluğu şeklindedir (Öztürk, Tanrıverdi ve Sapmaz, 2017).

Çetin ve Altıner (2019) 2016-2017 yılları arasında cinsel istismara maruz kaldığı için bakım ve koruma altına alınan kız çocukları ile çalışma gerçekleştirmişlerdir. Mağdur çocukların madde bağımlılığı ya da kötü alışkanlıklarının olduğu, intihar düşüncesini yoğun olarak yaşadıkları saptanmıştır. Psikolojik tedavi ve rehabilitasyon sürecine geçildiğinde ise bu duyguların zamanla azaldığı bulgulanmıştır. 
Yılmaz Irmak (2011) tarafından fiziksel istismara uğrayan ergenlerle yapılan bir çalışmada ergenlerde risk alma ve ruh sağlığı için anneye güvenli bağlanmanın koruyucu faktör, fiziksel istismar şiddetinin risk faktörü olduğu tespit edilmiştir.

Yurtdışı araştırmalara bakıldığında ise; çocuk istismarını önlemede okul temelli eğitim programlarının etkililiğini değerlendirmek amacıyla Amerika, Kanada, Türkiye gibi birçok ülkede yapılan bir çalışmanın sonucunda çocukların kendilerini koruyucu davranışları edinmeleri ve çocuk istismarı hakkında bilgilenmeleri konusunda uygulanan programın etkili olduğu saptanmıştır (Walsh vd., 2015).

Tutty (2000) tarafından yapılan çalışmada ise "Kime Anlatırsın?" başlıklı cinsel istismarı önleme programının etkililiğinin incelenmesi sonucunda uygulamaya katılan ilkokul çocuklarının istismar hakkındaki bilgi düzeylerinin arttığı ve güvenli- güvenli olmayan dokunuş arasındaki farkı daha iyi ifade edebildikleri saptanmıştır.

Hebert vd., (2001) yaptıkları bir araştırmada Amerikan Çocuk Saldırısını Önleme Programının (CAP) bir uyarlamasına katılan çocukların, katılmayan çocuklara göre daha fazla önleyici bilgi ve beceriye sahip oldukları bulgulanmıştır.

Macıntyre ve Carr (2000) tarafından yapılan çocuk istismarını önleme programlarına dair bir değerlendirme çalışmasında uygulanan programların hedef grup (çocuk, ebeveyn, öğretmen) için bilgi ve beceri kazanımı sağladığı bulgulanmıştır.

Binder ve Mcniel (1987) tarafından yapılan çalışma; çocuklar, ebeveynler ve öğretmenler ile gerçekleştirilen okul temelli çocuk cinsel istismarını önleme programının potansiyel istismar durumlarıyla başa çıkma stratejileri hakkındaki bilgilerinde önemli artış sağladığını göstermiştir. Çocuklar, programdan edindikleri bilgilerin kendilerini daha güvende hissettirdiğini ve kendilerini daha iyi koruyabildiklerini beyan etmişlerdir.

Amerika'da üniversite öğrencilerinin çocukluk döneminde çocuk istismarı önleme programına katılmış olmalarının çocuk cinsel istismar oranın azalmasıyla ilişkili olduğu saptanmıştır (Gibson ve Leitenberg, 2000).

Lee ve ark. (2012) tarafından yapılan çalışmada da aile içi şiddete maruz kalmış çocuklara uygulanan önleme programı sonucunda depresif semptomatolojide, psikososyal bozukluk semptomlarında ve bazı problemli davranışlarda genel bir düşüş olduğunu gözlemlenmiştir.

\section{YÖNTEM}

Araştırma betimsel tarama niteliğinde bir çalışmadır ve doküman inceleme yöntemi kullanılmıştır. Tarama modelleri geçmişte var olan ve araştırmaya konu olan olay, birey ya da nesneyi var olduğu şekliyle betimlemeyi amaçlar (Karasar, 2011:77). Doküman inceleme tekniği ise çalışmaya konu olan olgu veya olgular hakkında bilgi içeren yazılı materyallerin analizini içermektedir. Dokümanlar nitel çalışmalarda önemli bir bilgi kaynağıdır (Yıldırım ve Şimşek, 2016:189-190).

\section{Verilerin Toplanması}

Çalışmada sistematik tarama stratejisi belirlenmiştir. Öncelikle araştırmada yol gösterici olabilecek anahtar sözcükler belirlenmiştir. Buna göre kullanılan anahtar sözcükler; İstismar, Çocuk istismarı, Önleme, Müdahale olarak belirlenmiştir. Araştırma, Çocuk Hakları Sözleşmesi'nin Türkiye'de uygulanmaya başlandığı yıl olan 1995 yılından itibaren 2020 yılına 
kadarki süreçte, Türkiye'de uygulanmış ya da uygulanmakta olan istismar önleme programları ile sınırlandırılmıştır. Online ve tam metni erişime açık olan yayımlar (makaleler), lisansüstü tez çalışmaları incelenmiştir. Araştırmada birincil kaynak olarak Yükseköğretim Kurulu Başkanlığı Ulusal Tez Merkezi temel alınmıştır. Yine verilere ulaşabilmek için "Google Akademik" arama motoru ile Dergipark, Tr Dizin, Türk Psikologlar Derneği, Sosyal Hizmet Uzmanları Derneği ve online kütüphaneler kullanılmıştır. Belirtilen anahtar sözcükleri kullanılarak araştırma içeriğine ve sorularına uygun olan 33 makaleye ulaşılmıştır.

\section{Verilerin Analizi}

Ulaşılan makaleler, araştırma soruları açısından değerlendirilmiştir. Sonuçlar betimsel istatistik çerçevesinde tablolar halinde sunulmuştur. Her bir araştırma sorusu için makalelerin uygun bölümleri tekrarlı şekilde incelenmiş, sorularla ilintili olarak kategorilere göre sınıflandırmalar yapılmıştır. Her soru için uygulanan gruplama, bulgular kısmında açıklanmıştır.

\section{BULGULAR}

Toplam 33 makalenin incelenmesinden hareketle ulaşılan bulgular betimsel istatistik yöntemiyle analiz edilmiş ve aşağıda tablolar halinde gösterilmiştir.

Tablo 1. Araştırmanın Yürütüldüğü Bakanlıklara veya Kurumlara Göre Dağılımı

\begin{tabular}{lcc}
\hline & Araştırma & \\
Bakanlık & Sayısı (f) & $\%$ \\
\hline Millı̂ Eğitim Bakanlığı & 12 & 36,36 \\
Sağllk Bakanlığı & 2 & 6,06 \\
İçişleri Bakanlığı (Emniyet Gen. Müdürlüğü) & 1 & 3,03 \\
Kurum belirtilmemiş & 17 & 51,51 \\
\hline Toplam & 33 & 100,00 \\
\hline
\end{tabular}

Araştırmaların bakanlıklara göre dağılımı incelendiğinde; araştırmaların \%51,51'nin "Kurum belirtilmemiş" adı altında yürütüldüğü, bu oranı ise \%36,36 ile Millî Eğitim Bakanlığı'na, \%6.06 ile Sağlık Bakanlığı' na ve \%3,03 ile de İçişleri Bakanlığı bünyesinde Emniyet Genel Müdürlüğü'ne bağlı tek bir çalışmanın izlediği görülmektedir.

Tablo 2. Uygulamaların Önleme Programı Basamaklarına Göre Dağılımı

\begin{tabular}{lccc}
\hline Önleme Programı & Basamağı & $\mathrm{f}$ & $\%$ \\
& & 26 & 78,78 \\
\hline Birincil Önleme Programı & 5 & 15,15 \\
İkincil Önleme Programı & 2 & 6,06 \\
Üçüncül Önleme Programı & 33 & 100,00 \\
\hline Toplam & & \\
\hline
\end{tabular}

Tablo 2'ye bakıldığında araştırmaların \%78,8'nin "birincil önleme programları" adı altında yürütüldüğü, bu oran $\% 15,15$ ile ikincil önleme programları ve \%6,06 ile de üçüncül önleme programlarının izlediği görülmektedir. 
Tablo 3. Programların Uygulama Şekillerine Göre Dağılımı

\begin{tabular}{lcc}
\hline Uygulama Şekli & $f$ & $\%$ \\
\hline Eğitim verme & 26 & 78,78 \\
Broşür dağıtımı yoluyla eğitim & 3 & 9,09 \\
Bireysel Önleme & 4 & 12,12 \\
\hline Toplam & 33 & 100,00 \\
\hline
\end{tabular}

Tablo 3 incelendiğinde, araştırmaların \%78,78'inin eğitim şeklinde uygulandığı, bu oranı \%12,12 ile bireysel önleme ve \%9,09 ile eğitim ve broşür uygulamalarının izlediği görülmektedir.

Tablo 4. Programların Çalışma Gruplarına Göre Dağılımı

\begin{tabular}{lcc}
\hline Çalışma Grubu & Araştırma Sayısı (f) & $\%$ \\
\hline Ebeveyn & 9 & 27,27 \\
Ebeveyn ve Çocuk & 5 & 15,15 \\
Çocuk & 12 & 36,36 \\
Meslek Elemanı & 2 & 6,06 \\
Meslek Elemanı ve Ebeveyn & 1 & 3,03 \\
Üniversite Öğrencisi & 4 & 12,12 \\
\hline Toplam & 33 & 100,00 \\
\hline
\end{tabular}

Programların çalışma gruplarına göre dağılımı incelendiğinde; en fazla çocuklara yönelik $(\% 36,36)$ programlar şeklinde yürütüldüğü, bu oranı \%27,27 ile ebeveynlere yönelik programların ve \%15,15 ile hem ebeveyn hem de çocuklara yönelik programların izlediği görülmektedir. Ayrıca araştırmaları \%12,12'sini üniversite öğrencilerine yönelik programlar, $\% 6,06$ 'sını meslek elemanlarına yönelik programlar, \%3,03'ü hem meslek elemanı hem de ebeveynlere yönelik programlar oluşturmuştur.

Tablo 5 incelendiğinde programların en yüksek oranda $(\% 27,27)$ "aktif eğitim" adı altında yürütüldüğü, bu oranı \%12,12) ile "sunum" ve \%9,09 ile "belirtilmemiş" adı altında yürütülen programların izlediği görülmektedir. Sunum ve eğitici video, form kullanımı, hikâye haritası kullanımı, maket kullanımı, vaka sunumu, web tabanlı eğitim, kukla ve film kullanımı ise araştırmada aynı oranda $(\% 3,03)$ gözlemlenmiştir.

Tablo 6 incelendiğinde beceri edindirme ve bilgi düzeyi arttırma amacına yönelik çalışmaların aynı oranda ve ilk sırada $(\% 37,5)$ yer aldığı ikinci sırada ise yine aynı oranda $(\% 12,50)$ Tanılama ve istismar ihtimalini azaltma amaçlı çalışmaların yer aldığı görülmektedir.

Tablo 7 incelendiğinde, çalışmaların en fazla ön test-son test uygulamalı yarı deneysel/deneysel yöntem ile yürütüldügü $(\% 30,30)$, bu oranı $\% 27,27$ ile ön test-son test uygulamalı kontrol gruplu yarı deneysel / deneysel yöntemin ve \%18,18 ile ön test-son test-izleme testi uygulamal, kontrol gruplu yarı deneysel/deneysel yöntemin izlediği görülmektedir. Ayrıca araştırmalarda karma yöntem, görüşme tekniği ve denekler arası yoklama evreli çoklu yoklama modeli aynı oranda $(\% 6,06)$ kullanılmıştır. 
Tablo 5. Programların Özelliklerine Göre Dağılım

\begin{tabular}{lcc}
\hline Programın Özellikleri & Araştırma Sayısı (f) & $\%$ \\
\hline Aktif Eğitim & 9 & 27,27 \\
Sunum ve Eğitici Video & 1 & 3,03 \\
Eğitici Video & 2 & 6,06 \\
Form Kullanımı & 1 & 3,03 \\
Kişiye Özgü Çalışma Materyali & 2 & 6,06 \\
Hikâye Haritası Kullanımı & 1 & 3,03 \\
Etkileşimli Kitap Okuma Etkinliği & 2 & 6,06 \\
Sunum ve Eğitim Kitapçığı & 2 & 6,06 \\
Sunum & 4 & 12,12 \\
Çevre Düzenleme ve Terapi & 2 & 6,06 \\
Maket Kullanımlı & 1 & 3,03 \\
Vaka Sunumu & 1 & 3,03 \\
Web Tabanlı & 1 & 3,03 \\
Kukla ve Film Kullanımı & 1 & 3,03 \\
Belirtilmemiş & 3 & 9,09 \\
\hline Toplam & 33 & 100,00 \\
\hline
\end{tabular}

Tablo 6. Uygulanan Programların Amaçlarına Göre Dağılım

\begin{tabular}{lcc}
\hline Bulgular & Araştırma Sayısı (f) & $\%$ \\
\hline Tanılama & 4 & 12,50 \\
Bilgi Düzeyi Arttırma & 12 & 37,50 \\
Beceri Edindirme & 12 & 37,50 \\
İstismar İhtimalini Azaltma & 4 & 12,50 \\
\hline Toplam & 32 & 100,00 \\
\hline${ }^{*}$ İcelenen 33 araştırmadan birinde uygulanan programla ilgili bir bilgiye rastlanamadığı için toplam 32 araştırma veri \\
analizine dahil edilmiştir.
\end{tabular}

Tablo 7. Çalışmaların Araştırma Modeli/Desenine Göre Dağılımı

\begin{tabular}{|c|c|c|}
\hline Araştırma Model / Deseni & $\begin{array}{l}\text { Araştırma } \\
\text { Sayısı (f) }\end{array}$ & $\%$ \\
\hline Ön test-son test uygulamalı Kontrol gruplu yarı deneysel/deneysel & 9 & 27,27 \\
\hline Karma Yöntem (Nitel ve nicel yöntemlerin harmanı) & 2 & 6,06 \\
\hline Görüşme Tekniği & 2 & 6,06 \\
\hline Denekler arası yoklama evreli çoklu yoklama modeli & 2 & 6,06 \\
\hline $\begin{array}{l}\text { Ön test-son test-izleme testi uygulamalı Kontrol gruplu yarı } \\
\text { deneysel/deneysel yöntem }\end{array}$ & 6 & 18,18 \\
\hline Ön test - son test uygulamalı yarı deneysel / deneysel yöntem & 10 & 30,30 \\
\hline Doküman incelemesi & 2 & 6,06 \\
\hline Toplam & 33 & 100,00 \\
\hline
\end{tabular}


Tablo 8. Çalışmaların Ele Alınan İstismar Türüne Göre Dağılımı

\begin{tabular}{lcc}
\hline İstismar Türü & Araştırma Sayısı (f) & $\%$ \\
\hline Tüm İstismar türleri & 15 & 45,45 \\
Cinsel İstismar & 14 & 42,42 \\
Duygusal İstismar ve ihmal & 4 & 12,12 \\
\hline Toplam & 33 & 100,00 \\
\hline
\end{tabular}

Tablo 8'e bakıldığında, araştırmaların çoğunluğunun (\%45,45) tüm istismar türlerini içerdiği, bu oranı \%42,42 ile cinsel istismar ve \%12,12 ile duygusal istismar ve ihmali içeren çalışmaların izlediği görülmektedir.

Tablo 9. Çalışmaların Yıllara Göre Dağılımı

\begin{tabular}{lcc}
\hline Yayın Tarihleri & Araştırma Sayısı (f) & $\%$ \\
\hline 2010 ve öncesi & 3 & 9,09 \\
$2011-2015$ & 8 & 24,24 \\
$2016-2020$ & 22 & 66,66 \\
\hline Toplam & 33 & 100,00 \\
\hline
\end{tabular}

Araştırmaların yıllara göre dağılımı incelendiğinde; araştırmaların en fazla 2016-2020 yılları arasında yürütüldüğü $(\% 66,66)$, bu oranı 2011-2015 yılları arasında gerçekleştirilen çalışmaların izlediği $(\% 24,24)$ ve en az çalışmanın yapıldığı yılların ise 2010 ve öncesi olduğu $(\% 9,09)$ görülmüştür.

Tablo10. Uygulamaların Şehirlere Göre Dağılımı

\begin{tabular}{lcc}
\hline \multicolumn{1}{c}{ Şehir } & Araştırma Sayısı & $\%$ \\
\hline İzmir & 7 & 21,21 \\
Kırşehir & 2 & 6,06 \\
Ankara & 6 & 18,18 \\
Sivas & 2 & 6,06 \\
Ordu & 1 & 3,03 \\
Denizli & 2 & 6,06 \\
Samsun & 1 & 3,03 \\
Gümüşhane & 1 & 3,03 \\
Rize & 1 & 3,03 \\
Adana & 1 & 3,03 \\
Kocaeli & 1 & 3,03 \\
Kars & 1 & 3,03 \\
Belirtilmemiş & 7 & 21,21 \\
\hline Toplam & 33 & 100,00 \\
\hline
\end{tabular}

Araştırmaların şehirlere göre dağılımı incelendiğinde, araştırmaların çoğunun $(\% 21,21)$ İzmir'de ve $(\% 21,21)$ "Belirtilmemiş" adı altında yürütüldüğü, bu oranı ve \%18,18 ile Ankara şehrinin izlediği görülmüştür. Ayrıca Ordu, Samsun, Gümüşhane, Rize, Adana, Kocaeli, Kars şehirlerinde aynı oranda $(\% 3,03)$ araştırma gerçekleştirildiği görülmüştür. 


\section{TARTIŞMA ve SONUÇ}

Türkiye'de 1995-2020 yılları arasında istismar önleme programına dair yapılmış olan araştırmaların incelendiği çalışmada, araştırmaların bakanlıklara göre dağılımlarına bakıldığında, MEB bünyesinde ve/veya MEB ile bağlantılı $(\% 36,36)$ çalışmaların diğer bakanlıklara oranla daha yoğun olduğu görülmüştür. Sağlık Bakanlığı bünyesinde iki (2) çalışmanın $(\% 6,06)$ ve İçişleri Bakanlığı çatısı altında Emniyet Genel Müdürlüğü bünyesinde de tek bir çalışmanın yapıldığı, kalan 17 çalışmada ise $(\% 51,51)$ herhangi bir kurum adının belirtilmediği görülmüştür. Kurum adının belirtilmediği çalışmalarda, sadece çalışmanın gerçekleştirildiği yaş gruplarına ve öğrenim düzeylerine ilişkin bilgilere yer verilmiştir. Çalışmaların yürütüldüğü grup 18 yaş üstü üniversite öğrencileri ise kendilerinden, 18 yaş altı ise ebeveynlerinden onam formu alındığı belirtilmiştir. Yanısıra Aile ve Sosyal Hizmetler Bakanlığı'na bağlı merkezlerde rehabilitasyon çalışmalarının yürütüldüğü mağdur çocuklara dair var olan bilgilerine ulaşmak ve o kişiler ile temasa geçmek zorlu bir süreç olduğu için de araştırmacıların bakanlık izni gerektiren zorlu süreç yerine daha ulaşılabilir olan, bireysel izin veya ebeveyn onayıyla gerçekleştirebilecekleri uygulamaları tercih ettikleri düşünülebilir. Türkiye'de çocukların cinsel istismarına yönelik önleyici çalışmaların genellikle MEB çatısı altında rehber öğretmenlere yönelik gerçekleştirildiği belirtilmektedir (Kır, 2013). Bu durum çalışmadaki belirtilmiş bakanlıklar arasından MEB'e bağlı çalışmaların daha fazla olduğu bulgusunu destekler niteliktedir. İstismar konusunda hedef kitlenin ağırlıklı olarak anaokulu basamağından lise basamağına kadar olan öğrenim düzeylerinde olduğu düşünüldüğünde eğitimlerin daha çok MEB bünyesinde gerçekleştirilmiş olması açıklanabilir bir durumdur. Aynı zamanda hedef kitlenin büyük bir çoğunluğuna ve de daha kolay ulaşılabilecek olması, MEB'e bağlı kurumlarda okul temelli programların uygulamayı tercih sebebi haline getirmiş olabileceği düşünülebilir.

Ulaşılan araştırmaların önleme programlarına göre dağılımı incelendiğinde en çok birincil önleme $(\% 78,78)$ üzerine çalışma yapıldığı gözlemlenmiştir. Birincil önleme programları kişileri risk gruplarına ayırmadan, genel olarak ele alarak bilgilendirmeyi amaçlamaktadır. Öğretmen adayları ile yapılan çalışmada yarı yapılandırılmış görüşme formu ile elde edilen bilgilere göre katılımcıların çocuk istismarı ve ihmalinin belirlenmesi, önlenmesi ve müdahale süreci hakkında bilgi ve becerilerinin yeterli düzeyde olmadığı bilgisi edinilmiştir (Savi Çakar ve Yazıcı Okuyan,2017). Yine özel eğitimde çalışan öğretmenler ile yapılan çalışmada görüşme tekniği ile elde edilmiş bilgilere göre katılımcılar çocuk istismarı ile ilgili bilgilerini yetersiz gördüklerini, okul ortamlarında konuya yönelik yeterli bilgilendirme çalışmalarının yapılmadığını bildirmişlerdir (Toydemir ve Efilti,2019). Bu tarz araştırmalar göz önünde bulundurulduğunda araştırmacıların ihtiyaca yönelik olarak birincil önleme çalışmalarını daha çok tercih etmiş olabilecekleri düşünülebilir. Ayrıca Türkiye'de çocuk istismarı önleme girişimleri konusunda yetkili birimler il müdürlükleri, sosyal hizmet merkezleri ve çocuk koruma ilk değerlendirme birimleridir (Yaman ve Tuncay, 2020). Dolayısıyla bu birimlerden kişisel veri kaynaklarına erişimdeki zorluk nedeniyle araştırmacıların kişilere ulaşılabilirliği daha kolay olan gruplarla çalışmayı tercih etmiş olunabileceği düşünülebilir.

Araştırmaların programları uygulama şekillerine göre dağılımı incelendiğinde; eğitim verme $(\% 78,78)$ şekli üzerine yoğunlaştığı görülmektedir. Birçok ülkede de önleme programı olarak çoğunlukla eğitim verme yöntemi kullanılmaktadır. Çünkü bireysel önlemeye kıyasla aynı anda daha fazla bireye ulaşma bakımından oldukça avantajlı bir yöntemdir. Yanısıra yüz yüze etkileşimi de beraberinde getirmektedir ki bu avantajın broşür dağıtımı yoluyla eğitimde yer alamayacağı bilinen bir gerçektir. Bütün bu avantajlar nedeniyle doğrudan eğitim yönteminin ağırlıklı olması kaçınılmaz bir tercih nedeni olacaktır. 
Makaleler çalışma grubuna göre incelendiğinde ise, en fazla çalışılan grubun çocuklar $(\% 36,36)$ olduğu belirlenmiştir. On sekiz yaşına kadar her insan çocuk olarak sayılmaktadır. (UNICEF, 2004). 2015 yılında yapılan bir araştırmaya göre, Türkiye'de çocuk istismarı konusunda yapılan tezlerin örneklem grubunu ağırlıklı olarak çocuk ve ergenlerin oluşturduğu tespit edilmiştir (Beyazıt, 2015). Yine 2020 yılında ait başka bir çalışmada da aynı sonuç bulgulanmıştır (Hıdır ve Kılınç, 2020). Bahsedilen araştırmalar incelendiğinde 10-17 yaş aralığını ergen olarak tanımladıkları görülmüştür. Araştırmaların ergen grubu olarak tanımladığı grup bu çalışmadaki "Çocuk" olarak isimlendirilen gruba dahil olmaktadır. Tüm bilgiler göz önüne alındığında bu çalışmadaki bulguların önceki araştırmaları destekler nitelikte olduğu söylenebilir. Çocukluk döneminde yaşanan problemlerin derin izler bırakabileceği göz önünde bulundurulduğunda çocukların kendilerini korumayı öğrenmesi ve bilgi sahibi olmasının önem arz ettiği düşünülebilir.

Ulaşılan araştırmaların program özelliklerine göre dağılımına bakıldığında araştırmaların aktif eğitim $(\% 27,27)$ programların diğer özellikteki programlara oranla daha yoğun kullanıldığı saptanmıştır. Katılımcıların aktif olarak çeşitli uygulamalarla eğitim sürecine dahil olduğu yöntemin öğrenmedeki kalıcılı̆̆ı arttıracağı düşünüldüğü için en çok tercih edilen uygulama şekli haline gelmiş olabilir.

Programların amaçlarına göre dağılımına bakıldığında araştırmaların bilgi düzeyi arttırma $(\% 37,50)$ ve beceri edindirme $(\% 37,50)$ üzerine çalışmaların yoğunlaştığı görülmektedir. 2017 yılında öğretmen adayları ile gerçekleştirilen bir araştırmaya göre çocuk istismarının önlenmesi sürecine ilişkin bilgi ve becerilerinin yeterli düzeyde olmadığı bulgulanmıştır (Savi Çakan ve Yazıcı Okuyan, 2017). KKTC'de hemşireler ile yapılan çalışmada fiziksel istismar konusunda bilgi eksiklikleri olduğu saptanmıştır (Houssein ve Beratll, 2019). Bir hastanenin onkoloji bölümündeki ebeveynlerle yapılan bir araştırmada ebeveynlerin istismar ile ilgili bilgilendirici eğitimlere ihtiyaç duydukları saptanmıştır (Keser ve ark.,2010). Bu bulgulardan yola çıkarak ihtiyacın öngörülerek önleme programlarının içeriklerinin ihtiyaçlara uygun şekilde planladığ 1 düşünülebilir.

İncelenen araştırmaların desen/modellerine bakıldığında ön test-son test uygulamalı kontrol gruplu yarı deneysel/deneysel $(\% 27,27)$, ön test-son test-izleme testi uygulamalı kontrol gruplu yarı deneysel/deneysel $(\% 18,18)$ ve ön test-son test 38 uygulamalı yarı deneysel/deneysel $(\% 30,30)$ desenler diğer kullanılmış olan desenlere kıyasla daha çok tercih edilmiştir. Duygusal istismara yönelik yapılan tezlerin incelendiği bir araştırmada duygusal istismarla ilgili yapılan lisansüstü tezlerde kullanılan araştırma yöntemleri incelendiğinde en çok $(\% 75,06)$ nicel araştırma yönteminin kullanıldığı saptanmıştır (Kanak ve Çelik, 2018). Daha önce yapılmış olan araştırmalar kullanılan araştırma desenlerinden deneysel desenin oldukça az kullanıldığından bahsetmektedir. Yine çocuk istismarına dair yapılan araştırmalarda önleme programlarının da oldukça az olduğu tespit edilmiştir (Kanak ve Çelik, 2018; Bakır ve Kapucu, 2017; Beyazıt, 2015). Daha önce yapılmış araştırmalar ile farklı bulgular edinilme sebebi bu çalışmanın alan yazında oldukça az yapılmış olan araştırmalardan önleme programları üzerine odaklanması olabilir.

Ulaşılan araştırmaların eğildiği istismar türlerine bakıldığında tüm istismar türlerine yönelik $(\% 45,45)$ ve cinsel istismara yönelik $(\% 42,42)$ araştırmalar, duygusal istismar ve ihmale yönelik $(\% 12,12)$ araştırmalara göre daha çok tercih edilmiştir. Ekim 2016 tarihine kadar yapılmış çalışmaların incelendiği bir araştırmada, araştırmaların yöneldiği istismar türlerine bakıldığında çoğunlukla istismar ve ihmalin birlikte incelendiği saptanmıştır. Hemen ardından en çok bulgulanan istismar türü cinsel istismardır (Bakır ve Kapucu, 2017). Bu çalışmadaki bulgular da önceki araştırmaları destekler niteliktedir. Cinsel istismar saptanması en zor olan istismar türü olduğu için yapılan çalışmalarda cinsel istismar türüne ağırlık verilmiş olunabileceği düşünülmektedir. 
Araştırmaların yıllara göre dağılımına bakıldığında 2011-2015 yılları arasında (\%24,24) artış göstermeye başladığı, 2016-2020 yılları arasında $(\% 66,66)$ ise en fazla artışın olduğu saptanmıştır. Çocuk Hakları Sözleşmesi'nin Türkiye'de kabul edildiği yıl 1995'tir (Kök, 2019). Ulaşılan en eski tarihli araştırma 1998 yılına aittir. Bu süreçte çocuk istismarına dair birçok araştırma yapılsa da önleyici müdahalelere dair fazla araştırma yapılmadığı gözlemlenmiştir. Erkan (2018) yaptığı araştırmada 2010 yılından itibaren çocuk istismarı ile ilgili tez sayısında artış gerçekleştiğini gözlemlemiştir. Bu çalışmadaki bulgular da önceki araştırmaları destekler niteliktedir. 2010 yılında Çocuk İzlem Merkezleri faaliyete geçmiştir (Bağ ve Alşen, 2016). Çalışmada 2011-2015 yılları arasında önleyici müdahaleler dair araştırmaların artış göstermeye başladığı bulgulanmıştır. Hem istismar konusunda bilginin giderek artmaya başlamasının hem de devletin bu konuya daha fazla önem vermeye başlayarak Çocuk İzlem Merkezleri'ni faaliyete geçirmesinin ihtiyaca dair farkındalığı arttırmaya başladığı düşünülebilir.

Ulaşılan araştırmaların şehirlere göre dağılımına bakıldığında araştırmaların en fazla İzmir $(\% 21,21)$ ve Ankara'da $(\% 18,18)$ yoğunlaştı̆̆ 1 saptanmıştır. Yapılan alan yazın incelemelerinde ve kurumların halka açık verilerinde karşılaştırma yapılabilecek veriye ulaşılamamıştır. Ulaşılan bu bulgu; büyük şehirlerde yaşayan insan sayısının fazla olması ve bu sebeple daha fazla insanın bilgilendirilmeye ihtiyaç duyulmasından, büyük şehirlerde daha fazla üniversite bulunduğu için bu şehirlerde araştırma yapan kişi sayısının diğer şehirlere göre daha fazla olmasından kaynaklanıyor olabileceği düşünülebilir.

\section{ÖNERILLER}

1. Alan yazın tarandığında çocuk istismarı önleme programları ile ilgili oldukça yetersiz sayıda araştırmaya ulaşılabilmektedir. Bu konu üzerine daha çok araştırma yapılması uygulanan programları yeterliliklerini daha iyi görebilmesini sağlayabilir.

2. Risk grubunda bulunan ebeveyn ve çocukların korunması, tekrarlı istismarın önlenmesi konularının da en az toplum genelini istismara karşı bilgilendirmek kadar önemli olduğu için ikincil ve üçüncül önleme programlarına dair daha fazla çalışma gerçekleştirilerek bu gruplarla da çalışma sayısı arttırılabilir.

3. Katılımcıların aktif olarak eğitim sürecine dahil olduğu programların Türkiye'de daha sık uygulanarak öğrenmenin kalıcılı̆̆ı arttırılmaya çalışılabilir.

4. Çocuklar ile sürekli iletişim halinde olan anne, baba ve öğretmen gruplarında daha fazla çalışma yapılabilir.

5. Yapılan araştırmaların yoğunlukla bilgi düzeyi arttırma ve beceri edindirme üzerine odaklanmasına rağmen bu konularda eğitime ihtiyaç devam ettiği düşünüldüğünde bu konularda yapılan araştırmaların çoğaltılması düşünülebilir.

6. İstismar önleme programlarındaki sorunları tanımlayarak genel durumu değerlendirebilmek adına nitel çalışmalar arttırılabilir.

7. Deneysel desen kullanılarak gerçekleştirilen çalışmalar programın etkisinin yeterliliği, sorunlara çözümü üzerine odaklanabilmede daha yol gösterici olabilmektedir. Bu yüzden deneysel yöntem ile yapılan çalışmaların arttırılması istismar konusunda yapılan çalışmaların sorunlarının çözümüne daha fazla destek sağlayabilir.

8. Cinsel istismar saptanması en zor olan istismar türü olduğu bilinse de diğer istismar türlerinin de sonuçlarının derin izler bırakacağı bilinen bir gerçektir. Tüm istismar türlerini 
ele alan programlara ek olarak cinsel istismar dışındaki diğer istismar türleri için de önleme programlarının sayısı arttırılabilir.

9. Daha fazla şehirde araştırma yapılarak örneklem genişletilirse Türkiye geneli için araştırmaların verileri daha iyi değerlendirilebilir.

10. Bakanlıklara bağlı uygulanan önleme programlarının yeterliliklerini değerlendirebilmek amacıyla araştırmalar gerçekleştirilebilir.

\section{KAYNAKÇA}

Adalı, N. (2007). 10-12 Yaş Grubu Çocuk İstismarı Ebeveyn ve Çocuk Bilgilendirme Çalışması. Yayımlanmamış Yüksek Lisans Projesi. Ankara Üniversitesi Sosyal Bilimler Enstitüsü, Ankara.

Adli Sicil ve İstatistik Genel Müdürlüğü (2019). Adli İstatistikler 2019. Ankara. Https://Adlisicil.Adalet.Gov.Tr/Resimler/Sayfadokuman/1062020170359hizmeteozel-2019-

Bask\%C4\%B1-\%C4\%B0SA.Pdf. Erişim tarihi: 20/11/2020.

Acehan, S., Bilen, A., Ay, M. O., Gülen, M., Avcı, A. ve İçme, F. (2013). Çocuk İstismarı ve İhmalinin Değerlendirilmesi. Arşiv Kaynak Tarama Dergisi, 22(4):591-614.

Akgiray, A. (2007). Çocuk İstismarı: 8-10 Yaş Çocuklarda İstismar Önleme Yöntemleri. Yayımlanmamış Yüksek Lisans Projesi. Ankara Üniversitesi Sosyal Bilimler Enstitüsü, Ankara.

AACAP (1997). Practice Parameters Forthe Forensic Evaluation of Children and Adolescents Who May Have Been Physically Sexually Abused. J Amacad Child Adolescpsychiatry. 36 (10). 37-56.

Ata, Z. (2019). Geçmişten Günümüze Çocuk Mağduriyetleri. Sosyal Çalışma Dergisi, 3(1). 47-60.

Bağ, Ö. ve Alşen, S. (2016). Çocuğun Cinsel İstismarının Değerlendirilmesinde Yeni Model: Çocuk İzlem Merkezleri. Behçet Uz Çocuk Hastanesi Dergisi, 6(1):9-14.

Bakır, E. ve Kapucu, S. (2017). Çocuk İhmali ve İstismarının Türkiye'de Yapılan Araştırmalara Yansıması: Bir Literatür İncelemesi. Hacettepe Üniversitesi Hemşirelik Fakültesi Dergisi, 4(2), 13-24.

Bayraktar, S. (2015). İnsanlığın Kanayan Yarası Çocuk İstismarı ve İhmali. İstanbul: Nobel Tıp Kitabevi.

Beyazıt, U. (2015). Çocuk İstismarı Konusunda Türkiye'de Yapılan Lisansüstü Tezlerin İncelenmesi. Hacettepe Üniversitesi Sağllk Bilimleri Fakültesi Dergisi 1, 1-20.

Binder, R. L. and Mcniel, D. E. (1987). Evaluation of A School-Based Sexual Abuse Prevention Program: Cognitive and Emotional Effects. Child Abuse \& Neglect, 11(4), 497-506.

Çeçen Eroğul, A. R. ve Kaf Hasırcı, Ö. (2013). İlköğretim Birinci Kademe Öğrencilerine Yönelik Geliştirilen Cinsel İstismarı Önleme Psiko-Eğitim Programının Etkililiğinin Sınanması. Kuram ve Uygulamada Ĕ̆itim Bilimleri, 13 (2), 719-729.

Çetin, K. ve Altıner, H. (2019). Cinsel İstismara Uğramış Çocukların Sosyo-demografik Değerlendirilmesi. Necmettin Erbakan Üniversitesi Ereğli Eğitim Fakültesi Dergisi, 1(2), 135-147.

Demirtürk Selçuk, E. ve Karadeniz, H. (2020). Çocuk İstismarına Yol Açan Ailesel Nedenler ve Çocuğun Korunmasına Yönelik Önlemler. Sağlık ve Toplum Dergisi, 30(1), 30-35. 
Dursun, A. (2010). Okul Öncesi Dönemdeki Çocukların Davranış Problemleriyle Anne- Baba Tutumları Arasındaki İlişkinin İncelenmesi. Yayımlanmamış Yüksek Lisans Tezi, Dokuz Eylül Üniversitesi Eğitim Bilimleri Enstitüsü, İzmir

Erkan, I. (2018). Türkiye'de Çocuk İstismarı Konusunda Yayımlanan Lisansüstü Tezlerinin Adli Bilimler Açısından Değerlendirilmesi. Acıbadem Sağlık Bilimleri Dergisi, 9(4), 410-413.

Gibson, L. E. and Leitenberg, H. (2000). Child Sexual Abuse Prevention Programs: Do They Decrease the Occurrence of Child Sexual Abuse? Child Abuseand Neglect, 24 (9), 1115-1125.

Hebert, M., Lavoie, F., Piché, C. And Poitras, M. (2001). Proximate Effects of a Child Sexual Abuse Prevention Program in Elementary School Children. Child Abuse \& Neglect, 25(4), 505-522.

Hıdır, M. ve Kılınç, F. (2020). Çocukluk Döneminde Cinsel İstismar Üzerine Yapılan Çalışmalar İçerik Analizi. Türkiye Sağlık Araştırmaları Dergisi, 1 (1), 23-40.

Housseın, S. ve Beratlı, N. (2019). Kuzey Kıbris'ta Fiziksel Çocuk İstismarı Konusunda Hemşire Duyarlılığı. Journal of International Social Research, 12(65),1079-1099.

Kanak, M. ve Çelik, M. (2018). Türkiye'de Duygusal İstismar Üzerine Yazılan Lisansüstü Tezlerin Değerlendirilmesi. Turkish Studies Educational Sciences,13(27),907-920.

Kara, B., Biçer, Ü. ve Gökalp, A. S. (2004). Çocuk İstismarı. Çocuk Sağlığı ve Hastalıkları Dergisi (41). $140-151$.

Karasar, N. (2011). Bilimsel Araştırma Yöntemi. Ankara: Nobel Yayın Dağıtım.

Keser, N., Odabaş ve E., Elibüyük, S. (2010). Ana-Babaların Çocuk İstismarı ve İhmali Konusundaki Bilgi Düzeylerinin İncelenmesi. Türkiye Çocuk Hastalıkları Dergisi, 4(3), 150-157.

Kır, E. (2013). Çocuklara Yönelik Cinsel Taciz ve İstismara Karşı Önleyici Eğitim Çalışmaları. İstanbul Üniversitesi Hukuk Fakültesi Mecmuası, 71(1), 785-800.

Kök, H. (2019). Türkiye'de Cinsel İstismara Uğrayan Çocuklara Yönelik Hizmet ve Uygulamalarm Değerlendirilmesi: Bir Model Önerisi. Yayımlanmamış Doktora Tezi. Hacettepe Üniversitesi, Ankara.

Lee, J., Kolomer, S. and Thomsen, D. (2012). Evaluating the Effectiveness of an Intervention for Children Exposed to do Mesticviolence: A Preliminary Program Evaluation. Child Adolescsocwork J, 29: 357-372.

Macintyre, D. and Carr, A. (2000). Prevention of Child Sexual Abuse: Implications of Program evaluation Research. Child Abuse review: Journal of The British Association for The Study and Prevention of Child Abuse and Neglect, 9(3), 183-199.

Öztürk, M., Tanrıverdi, B. U. ve Sapmaz, Ş. Y. (2017). Cinsel İstismara Uğrayan Çocuk ve Ergenlerin Sosyodemografik ve Klinik Özelliklerinin Değerlendirilmesi, Psikopatoloji ve İlişkili Risk Etkenleri. Çocuk ve Gençlik Ruh Sağhlğ̆l Dergisi, 24 (2),155-163.

Polat, O. (2017). Tüm Boyutlarıyla Çocuk İstismarı-1, 2.Baskı, Ankara: Seçkin Yayıncllık.

Sarı, İ. ve Güngör Aytar A. (2015). Emniyet Örgütünde Görevli Anne - Babaların Fiziksel Çocuk İstismar Potansiyellerinin Belirlenmesi ve İstismarla İlgili Aile Eğitim Programının Etkililiği. Akademik Bakış Uluslararası Hakemli Sosyal Bilimler Dergisi, 51, 72-87 
Savi Çakar, F. ve Yazıcı Okuyan, H. (2017). Öğretmen Adaylarının Çocuk İstismarı ve İhmaline İlişkin Görüşleri. Mehmet Akif Ersoy Üniversitesi Eğitim Fakültesi Dergisi, (44), 250-275.

Siyez, D. M. (2003). Duygusal İstismara Maruz Kalan ve Kalmayan Ergenlerin Benlik Algılarn ile Depresyon ve Kaygı Düzeylerinin Karşılaştırılması. Yayımlanmamış Yüksek Lisans Tezi, Dokuz Eylül Üniversitesi, İzmir.

T.C. Sağlık Bakanlığı (2022). Çocuk İhmal ve İstismarı. https://hsgm.saglik.gov.tr/tr/ruhsagligi/ihmal-istismar.html. Erişim tarihi: 10/11/2020.

TDK (2020). https://sozluk.gov.tr/, Erişim Tarihi: 10/11/2020

Topçu, S. (1997). Çocuk ve Gençlerin Cinsel İstismarı, Ankara: Doruk Yayımcılık,

Toydemir, A. ve Efilti, E. (2019). Özel Eğitim Kurumlarında Çalışan Öğretmenlerin Çocuk İhmal ve İstismarına İlişkin Bilgi ve Farkındalık Düzeylerinin İncelenmesi. OPUS Uluslararası Toplum Araştırmaları Dergisi, 10 (17), 490-519.

Tutty, L. (2000). What Children Learn from Sexual Abuse Prevention Programs: Difficult Concepts and Development Alissues. Research on Social Work Practice, 10 (3), 275-300.

TÜİK (2020). Güvenlik Birimine Gelen veya Getirilen Çocuk İstatistikleri, 2015-2019 (Basın Bülteni). Https://Data.Tuik.Gov.Tr/Bulten/Index?P=Guvenlik-Birimine-Gelen-veya-Getirilen-CocukIstatistikleri-2015-2019-33632

UNICEF (2020). COVID-19: Getirilen Kısıtlamalar Giderek Artarken Çocuklara Yönelik İstismar, İhmal, Sömürü ve Şiddet Riski de Yükseliyor (Basın Bülteni).

Https://Www.UNICEF.Org/Turkey/Bas\%C4\%B1n-B\%C3\%Bcltenleri/Covid-19-Getirilen-

K\%C4\%B1s\%C4\%B1tlamalar-Giderek-Artarken-\%C3\%A7ocuklara-Y\%C3\%B6nelik-İstismarİhmal

UNICEF (2017). Şiddet ile Disiplin, Cinsel İstismar ve Cinayetler Tüm Dünyada Milyonlarca Çocuğun Peşini Bırakmıyor (Basın Bülteni). Https://Www.UNICEF.Org/Turkey/Bas\%C4\%B1nB\%C3\%Bcltenleri/UNICEF-\%C5\%9Fiddet-ile-Disiplin-Cinsel-İstismar-ve-Cinayetler-

$\mathrm{T} \% \mathrm{C} 3 \% \mathrm{Bcm}-\mathrm{D} \% \mathrm{C} 3 \%$ Bcnyada-Milyonlarca

UNICEF (2010). Türkiye'de Çocuk İstismarı ve Aile İçi Şiddet Araştırması.

Https:/Www.UNICEF.Org/Turkey/Sites/UNICEF.Org.Turkey/Files/2019-02/Cocuk-İstismariRaporu-Tr_1.Pdf

UNICEF (2004). Çocuk Haklarına Dair Sözleşme.

Https://Www.Unicefturk.Org/Public/Uploads/Files/UNICEF_Cocukhaklarinadairsozlesme.Pdf

Walsh, K., Zwi, K., Woolfenden, S. and Shlonsky, A. (2015). School-Based Education Programmes for the Prevention of Child Sexual Abuse. Cochrane Data Base of Systematic Reviews. Issue 4. Art. Https://Doi.Org/10.1002/14651858.CD004380.Pub3

World Health Organization (1999). Report of The Consultation on Child Abuse Prevention. 29-31 March,1999, Geneva.

Yaman, F. ve Tuncay, T. (2020). Ölümcül Çocuk İstismarları ve Türkiye Çocuk Koruma Sistemine Yönelik Bir Değerlendirme. Toplum ve Sosyal Hizmet, 31(3), 1370-1393.

Yıldırım Doğru, S. S. (2020). Çocuk Hakları ve Koruma Aile Refahı. 4. Baskı. Ankara: Eğiten Kitap Yayıncilik. 
Yıldırım, A. ve Şimşek H. (2016). Sosyal Bilimlerde Nitel Araştırma Yöntemleri. 11.Baskı. Ankara: Seçkin Yayıncılık.

Yılmaz Irmak, T. (2011). Fiziksel İstismara Uğrayan Ergenlerde Dayanıklılığın İncelenmesi. Ege Eğitim Dergisi, 12(2), 1-21.

Yılmaz Irmak, T. (2008). Çocuk İstismarı ve İhmalinin Yaygınlı̆̆ı ve Dayanıklılıkla İlişkili Faktörler. Yayınlanmamış Doktora Tezi, Ege Üniversitesi, İzmir.

Page, Z. A. (2004). Çocuk Cinsel İstismarı: Cinsel İstismara Neden Olan Etkenler ve Cinsel İstismarın Çocuklar Üzerindeki Etkileri. Türk Psikoloji Yazıları, 7(13), 103-113. 